\title{
FINAL GRANT REPORT
}

Appropriate Technology Grant

$\mathrm{DE}-\mathrm{FG} 44-80 \mathrm{R} 410255$

Low Cost Solar Room Kit

Table of Contents:

$1 \ldots \ldots \ldots$ summary

$2 \ldots \ldots \ldots$ Body of Report

9.......... Conclusions and Recommendations

$10 \ldots \ldots \ldots$ Photographs

$14 \ldots \ldots \ldots$. Property Certificates

Katiy Dakl

\section{DISCLAIMER}

This report was prepared as an account of work sponsored by an agency of the United States Guvernment. Neither the United States Government nor any agency thereof, nor any of their employees, makes any warranty, express or implied, or assumes any legal liability or responsibility for the accuracy, completeness, or usefulness of any information, apparatus, product, or process disclosed, or represents that its use would not infringe privately owned rights. Reference herein to any specific commercial product, process, or service by trade name, trademark, manufacturer, or otherwise does not necessarily constitute or imply its endorsement, recommendation, or favoring by the United States Government or any agency thereof. The views and opinions of authors expressed herein do not necessarily state or reflect those of the United States Government or any agency thereof. 


\section{DISCLAIMER}

This report was prepared as an account of work sponsored by an agency of the United States Government. Neither the United States Government nor any agency Thereof, nor any of their employees, makes any warranty, express or implied, or assumes any legal liability or responsibility for the accuracy, completeness, or usefulness of any information, apparatus, product, or process disclosed, or represents that its use would not infringe privately owned rights. Reference herein to any specific commercial product, process, or service by trade name, trademark, manufacturer, or otherwise does not necessarily constitute or imply its endorsement, recommendation, or favoring by the United States Government or any agency thereof. The views and opinions of authors expressed herein do not necessarily state or reflect those of the United States Government or any agency thereof. 


\section{DISCLAIMER}

Portions of this document may be illegible in electronic image products. Images are produced from the best available original document. 
Summary

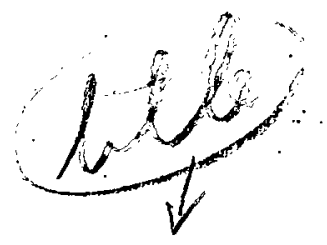

Grant funds were used to develop a low -cost solar room kit which would make use of local framing materials, but provide inexperienced biuilders with a simple joining system and materials--such as glazings-not usually available in local stores. Since solar room applications are proven effective in providing supplementary home heat, a kit would make solar heat more accessible to home owners and tenants. Although a prototype and two working models of the kit were successfully built through the grant, commercial development cannot occur until problems in matching the glazing and framing system can be resolved, and more capital to lower production costs on the framing union pieces is available. While more time and funds are needed to fully develop the kit, most grant goals were reached and completion will be pursued independently. 


\section{Body of Report}

The original objective of this grant was to develop a low cost solar room kit. A solar greenhouse or sunspace is a practical and cost effective way to use solär energy for home heating. Many people who could benefit from a solar room do not have the carpentry skills, tools, or experience to build their own. Many more cannot affort construction costs or the price of a nationally marketed solar room kit. Grant funds were planned to be used to develop a pre cut solar room kit using local materials and labor and to build two models of the kit. The perfected kit would make a solar room more accessible to the community through it's easy assembly and low cost. The proposed solar room was to be based on the design for a solar room promoted by Garden Way publishing company.

Initial research after the grant award was made led me to change the originally proposed room design and modular approach for a more simple and less expensive design. It became apparent that the Garden Way design could not be produced in a pre cut or modular fashion without more funds for materials and labor, and more elaborate production facilities. Even if this were available, the final kit would not meet the easy assembly and low cost criteria outlined in the grant application. Grant activities were shortly thereafter geared towards developing a. more acceptable kit system that could better meet grant expectations. 
The design that resulted used roof and front wall $2 \times 4$ members all cut the same and attached at the sill plate, ledger board, and to each other in 19

in the middle by metal joining pieces and metal hangers.

Carriage bolts fastened the wood to the joining pieces, so the framework could be assembled and taken apart with a screwdiriver and wrench. The frame was given horizontal stability by a galvanized pipe run through holes' drilled in the front wall and roof members.

This design seemed good, because it would allow a person to use whatever grade lumber he/she wanted to chose, or even recycled building materials. Cost of the framework could thus be determined individually and framing mater: ials would not need to be included in the kit. The simple joint pieces could be easily shipped, amking widespread kit distribution more feasible.

A simple cardboard template could be used to show the do-it-yourselfer where the framing members were to be cut and drilled to accept the joint pieces. The lightweight frame could be placed on a simple railroad tie or treated wosd foundation, eliminating the extra expense of a full foundation.

The first model was built on a deck where double windows opening into a living room area would allow for heat transfer. The deck was treated underneath with creosote, and above with a nontoxic oil preservative. After construction, a vapor barrier was added, the underneath insulated with a reflective foil insulation, and the deck covered with brick for thermal mass.

Outside help was solicited for construction and for fabricating the metal joining pieces. I learned that my design could be made, but since each would be hand produced and the end hangers individually spot welded, they would be expensive. I learned unit costs could be reduced if a die to punch out 
the parts were made. Since the two dies would cost about $\$ 500$ each, I opted to have them hand made for these models.

The dimensions of the original hangers were enlarged. Although they were built with $11 / 2 "$ slots to accept standard lumber, the $2 \mathrm{x}$ 's would not fit smoothly in the hangers unless they were planed.

Because each hanger was hand made, I found I could not rely on a template to pre drill the carriage bolt holes. Each framing member had to be drilled to match it's own hanger, making construction more difficult and time consuming.

I concluded from this experience that in order to develop the kit for public use, dies would have to be made. This would reduce unit cost in the long run and insure that the joint pieces were uniform and that the template system for precutting and drilling the frame would work.

Once the first model framing system was erected, it proved to be extremely strong and stable. Several adults could hang from the structure without affecting it in any way. Sidewalls were framed to accept siding, a door, and a vent fan. I had decided to make the sidewalls solid to lower heat loss. After working on the sidewalls, I decided that fiting a framework into the angled opening would be too difficult for most do-it-yourselfers, and that it would probably be better to go with a more simple glazed sidewall in future models. to simply the structure. Simple nightwall panels could be used on the glazed surfaces as moveable window insulation, and framing could be limited to the door and vent openings. 
I had originally planned to use Kalwall fiberglass sheeting for the glazing. It has good solar properties, and with an EDPM extrusion made by Lane Maxwell enterprises, would be easy to seal. The glazing could be rolled from the top to the bottom in 4 foot wide rolls to match the framing, which was placed on two foot centers. In planning my glazing, I neglected to make sure that the fiberglass sheeting would bend at the angle where the roof and south wall framing members met. It would not bend a such an angle without stress cracks. I found if we sliced the $2 \mathrm{x}$ members at the angle to produce three, rather than two angles, the fiberglass would conform to the frame's shape.

We disassembled the frame and re cut the middle pieces. When we reapplied the fiberglass to one section and used the EDPM gasket, I found I still could not get the materials to seal properly.

This was a significant problem and solving it on a timely basis was important because I had scheduled space at a public exhibit to display a kit section to help get feedback from the community and evaluate the kits' commercial potential.

I located another glazing called Flexgard, manufactured by $3-\mathrm{M}$. It was clear, had an expected life of 10 years, good solar properties, reasonable in cost, and the sample I had seembed flexible enough to make the middle framing bend. 3-M recommended use of a double adhesive foam tape it manufactures for attaching the film to the framing. It also recommended an adhesive foil surfaced tape to seal the Flexgard on the top. 
I did not think the foil tape on the outside would be acceptable to the public as it looked like wrinkled aluminum duct tape. My plan was to go ahead with thin cedar strips as battens, using the 3-M foam tape between the glazing and batten to seal the system.

I ordered the Flexgard roll, but learned that the foam adhesive tape recommended for use with the Flexgard was made by another division of 3-M. When I located that division, I was told I could only order the pate in case quantities. Since I only needed a couple of rolls, and did not want to spend hundreds for a case when three rolls would suffice, I was referred to a local sales representative for assistance. After tracking him down, he set up a :one time small order for me. Delivery took place after more follow-up calls and shipping problems. This delayed construction progress on the first full sized model by several months.

In the meantime, I did construct a kit section for the home show, using Flexgard and an imperfect EDPM seal. The kit concept was well received. Over 300 people took flyers describing the project and several dozen interested people asked to be contacted when the kit was ready to be sold. I learned most people wanted the option of purchasing pre-cut and drilled framing members and that they found the clear Flexgard glazing very acceptable.

When the 3-M sealing tape arrived, I used it as planned to attach the glazing to the wood främe and cushion and seal the batten. The glazing was rolled from the top to the bottom in 4 foot wide sections. Battens ripped from cedar stock were screwed in place so they could be removed easily. The glazing was secured on each framing member placed on the two foot center to prevent wind damage. You will notice from the pictures enclosed that 
small pieces of batten material were applied to the model where the middle joint angle was smoothed to accept the original fiberglass glazing.

When the room was glazed it immediately became overheated in the late summer sun. A vent fan with a simple thermostat provided relief and mylar sheets were:pinned to the underside of the roof frame to provide shade. Later, in the fall, the room made supplementary heat on sunny days in the attached 800 sq. foot house unneccessary.

After the first few days that the glazing had been applied, though, the Flexgard developed an opaque streak in one section about eight inches long. Shortly thereafter, another flaw appeared. Both appeared to start where the battens had been screwed through the glazing to the frame. I have concluded that uneven pressure on the Flexgard will produce runs. and that these appeared after wind aggravated stress on the glazing.

I was not sure of the extent of this problem until the second model was built. This model is a somewhat smaller unit attached to windows in an older home in Lexington, Ky. The design uses the same joint system, but the hangers were redesigned to fit the compact size of this room. The hanger system proved to be as sturdy and easy to work with as on the first model. Since this model would be used for both heat and plant production, it was to be double glazed with teflon film stapled to the inside, and equipped with two automatic "solar vents" to prevent summertime overheating.

The builder of this second model used nails instead of screws to secure the supplied batters, and even more flaws showed up in the Flexgard. The appearance was such that I knew a more foolproof method of gently securing the glazing would have to be found if the kit were to be developed commercially. 
This second model, built by Peter Wilcox on the side of a rented home, is , Peter says, providing perhaps a total season.- supplementary heat of up to $20 \%$ in addition to starting summer garden plants and a place for late fall plant production. He is monitoring room temperatures using a min-max thermometer. Since Peter has been newly elected head of the Kentucky Solar Coalition, I expect he will be able to use the kit as part of his continuing efforts to demonstrate and publicize appropriate technology. 
Conclusions and Recommendations

A. The framing system developed for this kit is stable, strong, and easy to assemble, thus meeting grant goals.

- B. The metal hanger/joiner system will need to be die cut to insure uniformity and easy construction if the kit is to be commercially developed.

C. The system of fastening Flexgard glazing to the framework needs to be improved to eliminate stress marks in the glazing.

D. The general public seems receptive to the kit design, but would like to have framing members pre-cut as an option.

E. The solar room models developed through the grant are performing successfully in providing supplementary home heat and food despite "bugs" that need to be eliminated.

F. Through public display, newspaper articles, and a locally produced TV show (Kentucky Journel, PBS) thousands of community members learned about the grant program, more about solar applications, and about solar rooms in particular. The second model, as proposed in the grant, is in a location where it's use will continue to publicize the project.

G. Although I thought I had researched my proposal well, I found I had underestimated time, costs, and made expensive mistakes. Much effort was spent arriving at workable ideas and more money and time will be needed to independently pursue kit development. It was a great opportunity though, an excellent learning experience, and the - grant project activities will be continued over the upcoming months. 


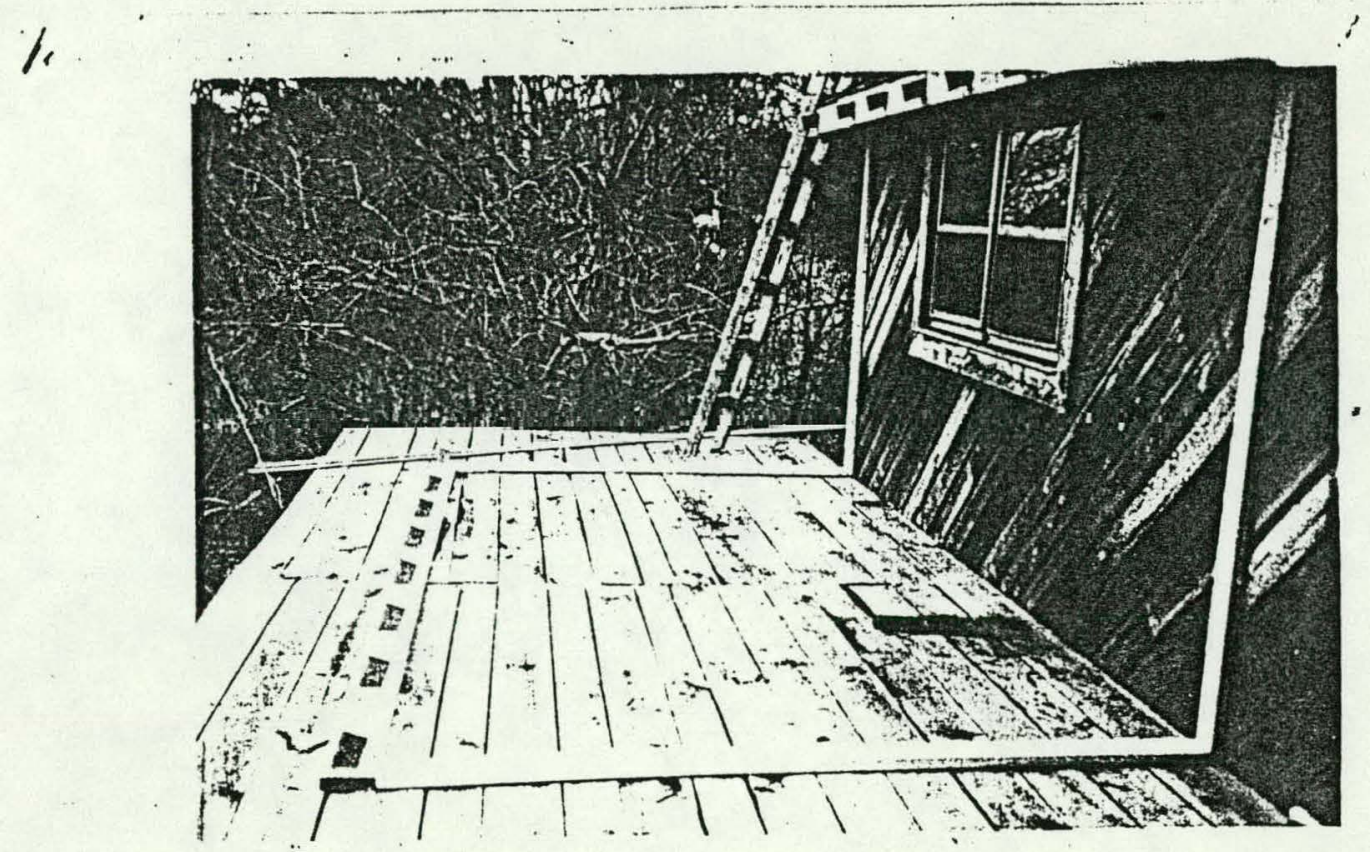
Preparation of ledger boards and sill plates with
brackets in place to receive framing lumber

2.

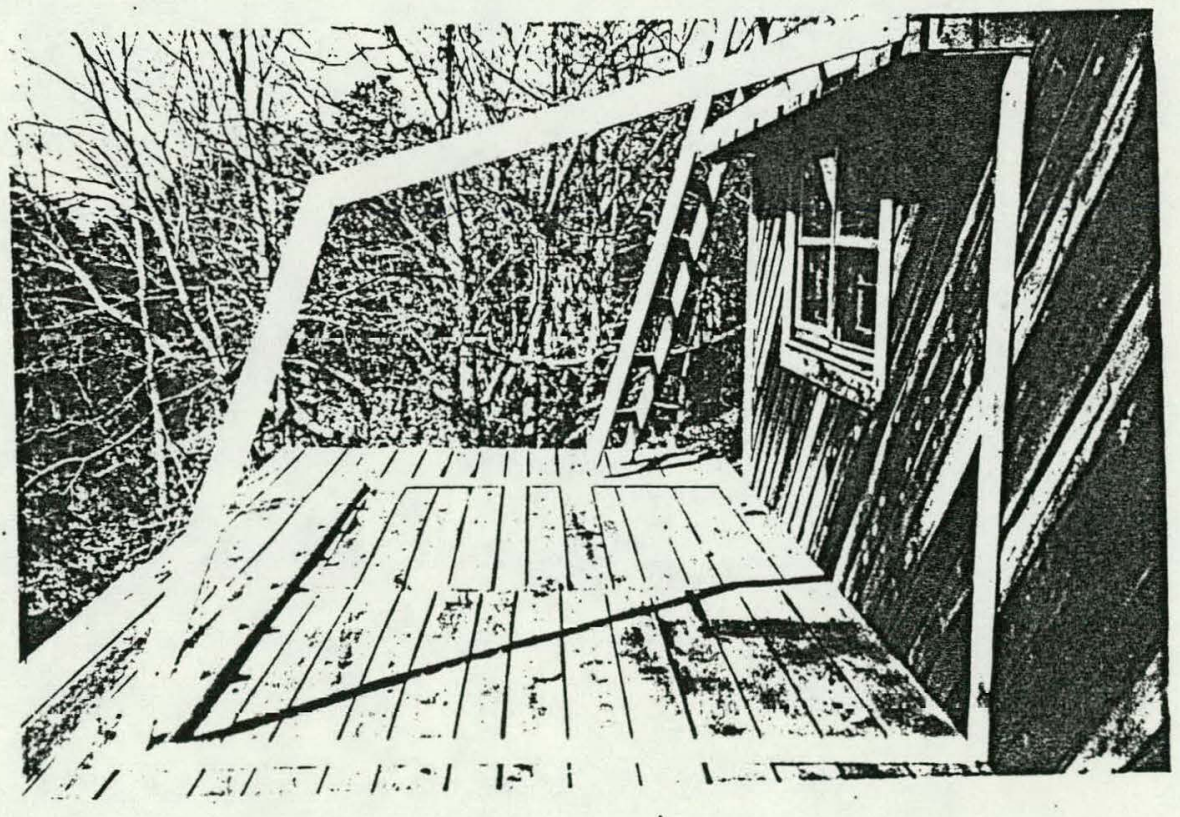

Framing members fitted into place to take mid section connectors. 
3.

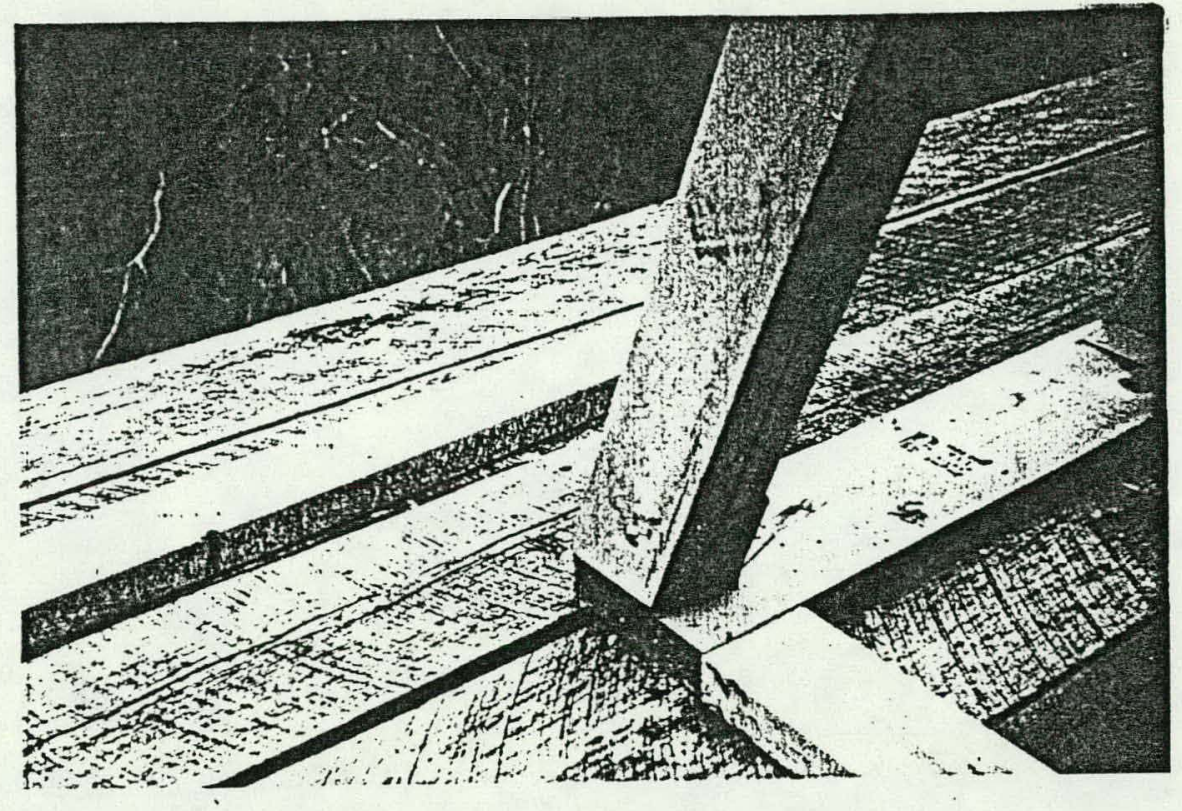

Detail of outside corner

भ,

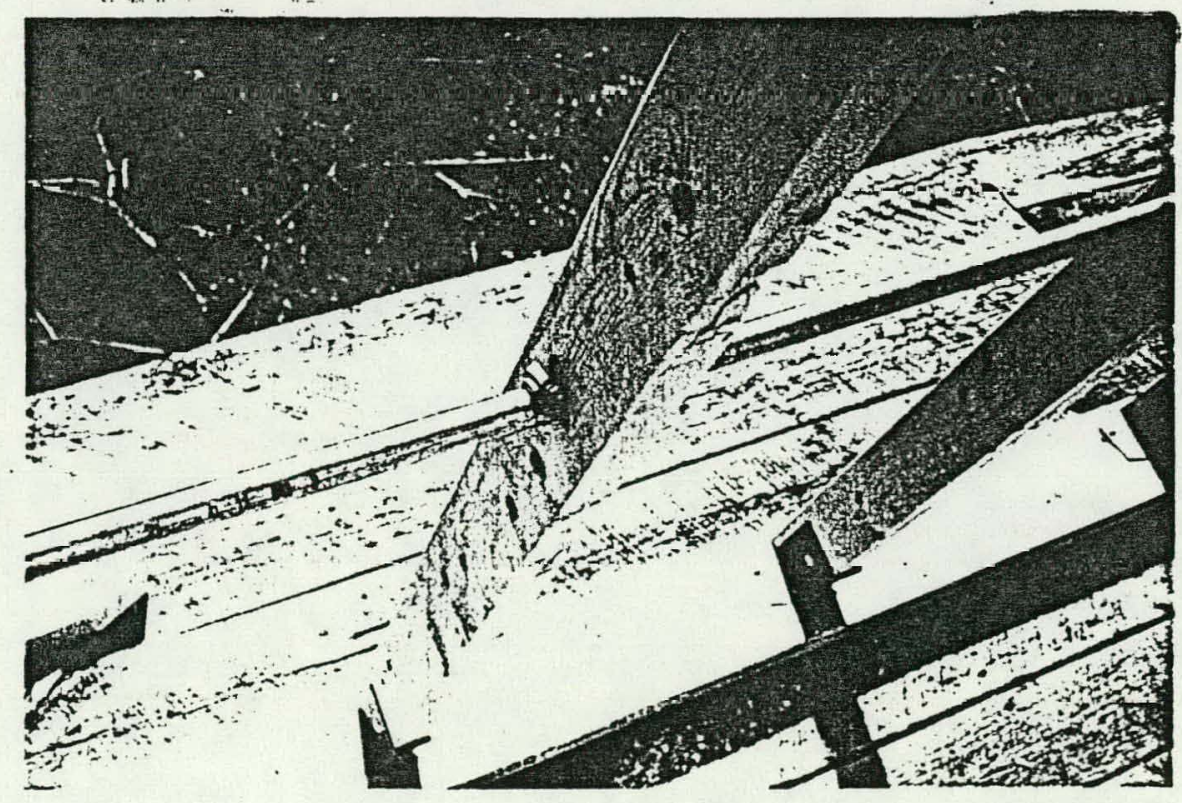

Detail of center support system using galvanjzed pipe 
ร.

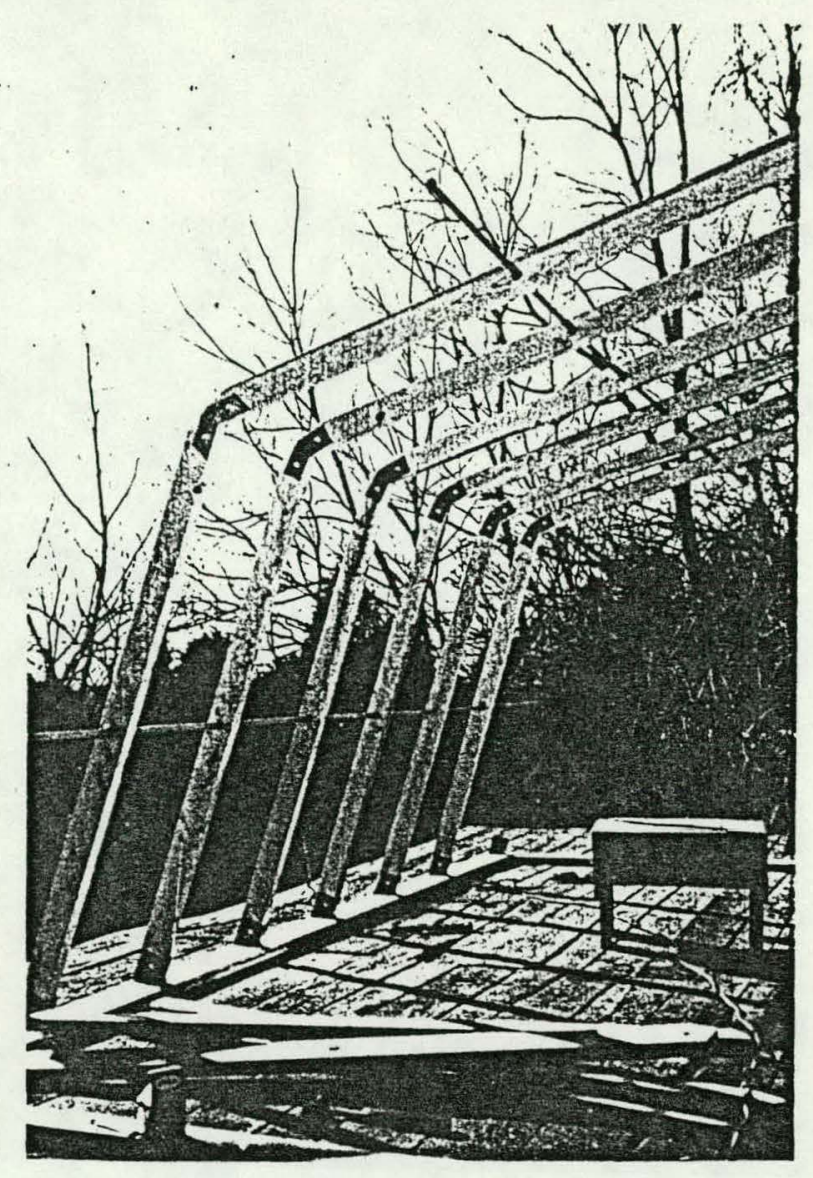

(1)

Partially framed room

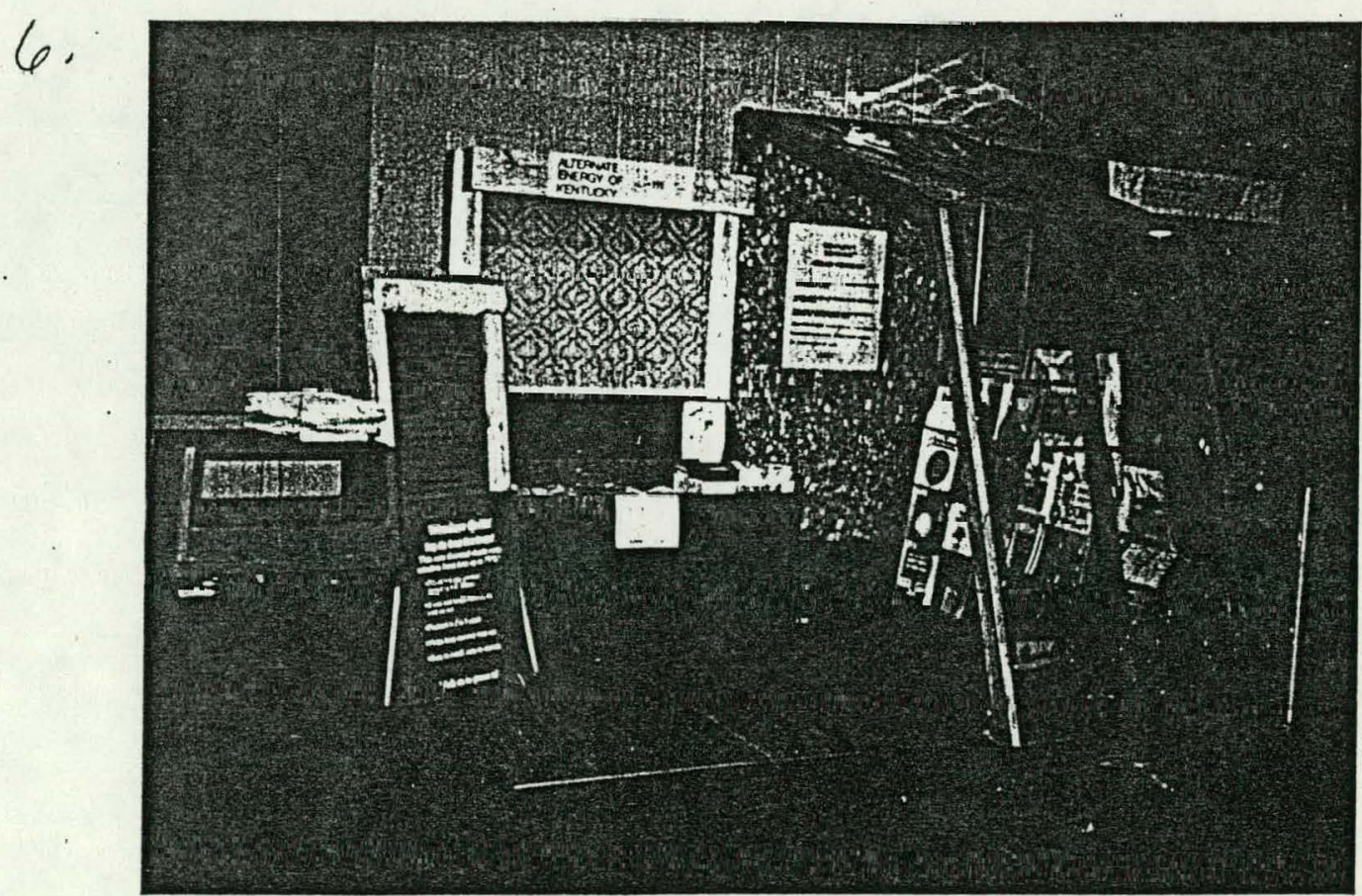

Model on display at: Central Kentukky Home and Garden Show 3-81 to help determine market reaction 
7

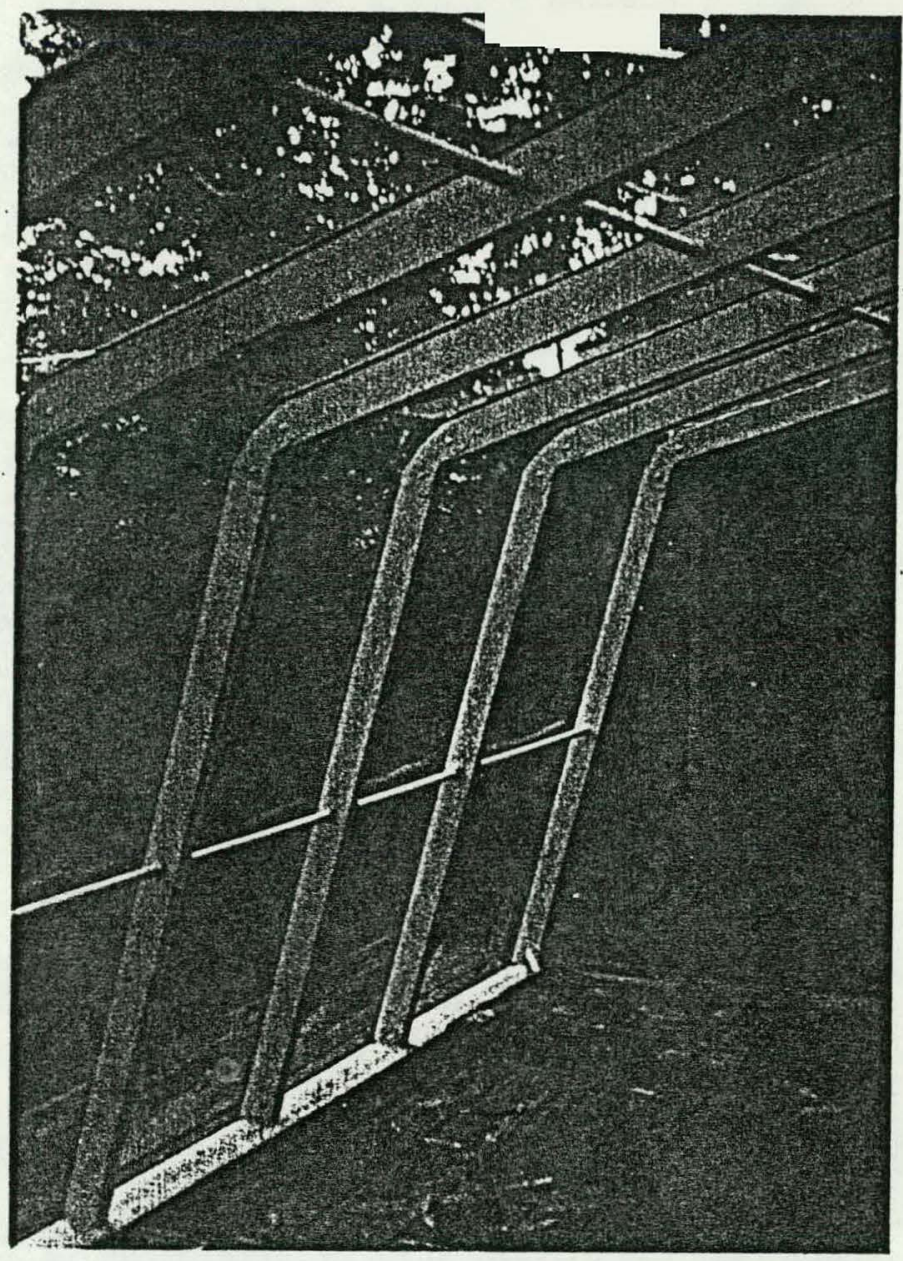

Partially completed room, glazing in place--interior view

8.

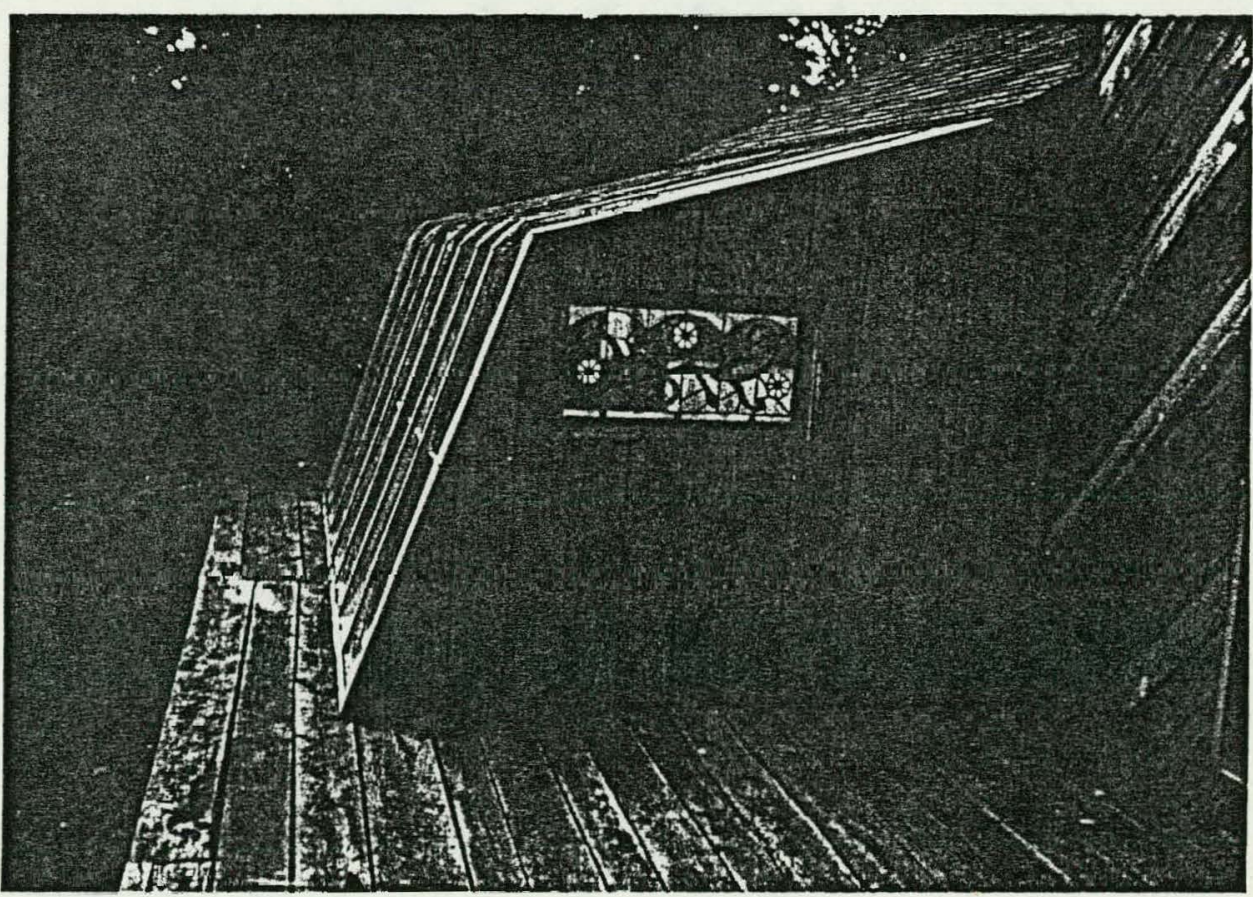

Partially completed room, exterior view ( stained glass not included in grant costs) 